\title{
PESANTREN LITERATURE IN INDONESIAN LITERATURE CONSTELLATION
}

\author{
Sri Muniroch
}

srimuniroch@yahoo.co.id

University of Queensland

28 Baty Street, St. Lucia, QLD 4067 Australia

\begin{abstract}
Pesantren literature challenges an issue of confession and acceptance in Indonesian literature. Questions on pesantren literature are concerned with the existence and literary quality of the works included in the category of pesantren literature. The important question is whether the works have literary uniqueness as specific genre that can be distinguished from other kinds of literary works. This article will not identify the literary quality of pesantren literature but tries to discuss the existence of pesantren literature among other Indonesian literary works. The discussion is expected to give an alternative perspective on the position of pesantren literature in the whole constellation of Indonesian literature.
\end{abstract}

Keywords: pesantren literature, Islamic literature, Indonesian literature

\section{INTRODUCTION}

Indonesian literature in the beginning of twenty first century witnessed the emergence of a large number of novelists with pesantren (Islamic boarding school) background. Their existence was very significant due to the booming of their works and the influence to other media, such as film and television, in the forms of the novel adaptation into films and soap operas (Hoesterey and Clark, 2012; Rani, 2012). By this time, the term sastra pesantren (pesantren literature) was debated and became controversy in the media, such as newspaper and Internet. Two different opinions spread concerning the appropriateness of the term pesantren literature existing in Indonesian literature. They who agreed on the importance of pesantren literature argued that group of writers coming from pesantren really existed in Indonesian literature with their specific works, while the others asked about the uniqueness of the so-called pesantren literature so that it can be identified as a specific genre different from the existing kind of works written by Indonesian writers in general. The polemic made the issues on pesantren literature important in the discussion of Indonesian literature.

The debate on the position of pesantren literature is closely related to the importance of pesantren in Indonesian Muslim society. Pesantren as the one of oldesttraditional educational institution have strategic function for the development of Muslim society along the history of Indonesia since the sixteenth century (Srimulyani, 2007, p. 85). This institution role in bearing many important leaders strengthens its position in Indonesian social and political life. As a country with Muslim majority, pesantrens are considered influential due to their existence as established educational institutions rooted in traditional society with their strong tradition and root that have great influence in Indonesian society and politics, in spite of the complex relation between pesantren and the state in Indonesian history (Sirry, 2010).

The important position of pesantren makes the issue of pesantren literature significant in the discussion of Indonesian literature. In the history of Indonesian literature many writers from pesantren have existed since the beginning era of modern Indonesian literature. However, they have 
never been identified as pesantren writers but only Muslim writers instead due to their only concern on Islam in general without any presentation of their pesantren background in their works. Before the last years of twentieth century and the beginning of twenty first century there was only the categorization of Islamic literature regarding the religious themes the writers suggest in their works. Once Abdurrahman Wahid has ever discussed about writers from pesantren (Wahid, 1973) and A. Teeuw (1989) and Sumardjo (1992) identified one prominent writer with pesantren background, Djamil Suherman who presented pesantren life in his work, UmiKalsum (1963), but then the issue disappeared until the last years of twentieth century and the beginning of the twenty first century when the term pesantren literature became an important issue in Indonesian literature.

The mushrooming of novels by pesantren writers in the last decade shows the significance of such novels in Indonesian literature and for Muslim society as well. Many discussions on this new phenomenon result in various reasons of the emergence of pesantren literature, among other things, due to the Muslim celebration after the suppression in the New Order era, the emergence of new middle class Muslim society, the commodification of Islam, and the influence of the rise of global Muslim religious spirit (Hoesterey and Clark, 2012). Studies on novels by pesantren literature are mostly related to popular culture, Islamic literature in general, and pesantren literature in the form of traditional Islamic poems developed in Pesantrens (Rani, 2012; Abdullah, 1996). Such novels written by contemporary pesantren writers have not got any specific attention while in fact they really exist as specific literary forms compared to the existing literary works in Indonesia at least in terms of themes and diction, the two literary elements that can be considered as distinctive elements to distinguish one literary form to the others. This can be a reasonable argument to conduct a specific study on the novels by pesantren writers separately. Some studies take it for granted that pesantren literature has really existed as a different genre in Indonesian literature, even there has been a subgenre generated from it, that is, popular pesantren literature that refers to the novels written by young writers from pesantren with similar characteristics as chick lit or teen lit, that is, the use of colloquial language, and specifically in popular pesantren literature, the use of specific words used by young students of pesantren (Ismah, 2011; Dewi, 2011). Considering the results of the studies, there should be no debates or controversy about the existence of pesantren literature. However, this article is going to take the debates as starting point to find out the real existence of pesantren literature.

The specific characteristics of the novels written by contemporary pesantren writers can be identified from the distinguished religious theme and the presentation of pesantren tradition in their works. This makes them different from the previous generation of pesantren writers who mostly wrote poems and did not specifically explore pesantren tradition. In spite of the same religious themes suggested by both generations of pesantren writers, the contemporary pesantren writers write in more acceptable way for common people with easy language while the previous generation used more difficult language and imagery that needs further interpretation to understand it. This can be the reason why people in common like reading novels more than poems that contributes to the popularity of novels, including novels by contemporary pesantren novels that become best sellers, not only the novels but also the film versions (Rani, 2012; Imanda, 2012). The people's enthusiasm, and in turn support from publishers, on pesantren novels gives a great opportunity for pesantren writers to actively write so that their novels can be easily found in the bookstores and many new names of pesantren writers appeared. To this condition, support from some Islamic literary movements and communities should be counted, such as Forum Lingkar Pena (Pen Circle Forum) and Matapena with their corresponding publishers that have mission and aims to publish Islamic novels. These organizations have made various groups of writers possible to be recognized in Indonesian literature. In general, the term Islamic literature is used to refer to all literary works containing Islamic values from which pesantren literature and popular pesantren literature are generated. This article tries to 
describe the map of contemporary Islamic literature. This may become one of the significances of this article in side by side with the effort to find the map of the genre of pesantren literature in Indonesia literature.

\section{Indonesian Islamic Literature: An Overview}

Islamic literature has always become inseparable discourse in the entire history of Indonesian literature since the beginning, even before the period of modern Indonesian literature, the time after the use of Bahasa Indonesia as unifying language formally acknowledged in the 1928 Indonesian Youth Congress. The pope of Indonesian literature, H.B. Jassin, has tried to define the specific literary genre of the early period. His definition refers not merely to the religious background of the writers but specifically to the content that should show the writers' religious ideas and the literary quality of the works (Jassin, 1985, p. 138). Hamka, a prominent Indonesian Muslim writer and a religious leader, gave stronger emphasis on the difference between orthodox Sufi belief and non-orthodox teaching in his guidelines of an Islamic literature (Osman and Nasir, 2011). Emha Ainun Nadjib, a younger generation Indonesian Muslim writer, distinguished between "Sastra Islam" (Islamic literature) that refers to the works by Muslim writers and "Sastra Islami" (literature of Islam) that includes works by non-Muslim writers (Osman and Nasir, 2011). This definition seems too simple but Emha stressed more on the person writing the literary works. His definition represents the idea that Islamic literature illuminates the religious insights of a writer's inner thought because only Muslim writers can deeply absorb the religious nerves of Islam, while literature of Islam only calls for the idea about Islam and it can be done by anyone concerning himself with Islam. In accordance with Emha, a contemporary Muslim woman writer, Rosa (2003), identified the difference between sastra Islam (Islamic literature) and sastra berdasarkan Islam (Islam-based literature). She proposes the requisites of sastra Islam that include: a) the writers should be Muslims who realize and have responsibilities for the purity of their religion and write as the expression of their religious service for God and people, b) their work should be in line with Islamic teachings, and c) their works should have universal message, give benefits for all people and show both creativity and esthetic values. On the other hand, sastra berdasarkan Islam refers to literary works with Islamic values regardless the writers' religion, such as works of Kahlil Gibran. Concluding all definitions, Musa (2012) gives his general definition of Islamic literature, that is, literature inspired by broad concept of Islamic arts with the base of Islamic belief and conduct emphasizing on the truth more than beauty but still considering the standard literary quality. It must present good impression and put emphasis on the goodness (makruf) and Islamic principles.

In the discussion of Islamic literature in Indonesia, pesantren literature is the other discourse that should be included because since the beginning it has existed in Indonesian literature history. The division of Indonesian literature history into periods by Indonesian literary experts has not identified pesantren literature as specific genre while there have been many writers from pesantren and literary works concerning the life of pesantren along the history of Indonesian literature. In the historical aspects, Indonesian Islamic literature and pesantren literature might have a different pave, especially in the beginning period. In the earlier period of Indonesian literature in broader scope, works of Islamic literature were created in Arabic or translated from Arabic into Indonesian by mostly unknown writers. Hamzah Fansuri living at the end of sixteenth century to the beginning of seventeenth century is considered as the representative of Islamic literature writers. In narrower scope, meaning the literary works have used Indonesian language, works of Islamic literature have been found before the twentieth century in the forms of hikayat (saga), syair (verse), and pantun (Indonesian specific traditional verse) (Jassin, 1985). In the next era, Pujangga Baru, the era after the 1928 Youth Pledge, Jassin identified there were quite many Muslim writers with works that can be categorized as Islamic literature.

The next era witnessed only few Islamic literature writers in the upheaval of many ideologies in the new nation Indonesia, even though a Muslim weekly Bintang (Star) published in Medan "had a cultural 
supplement Gerkis (Gerakan Kesusasteraan Islam = Islamic Literary Movement)" (Teeuw, 1994, p. 117). In the nation with Islam as the religion of the majority, religious affairs is so prominently important in all aspects of the people's life that discussing religion sometimes becomes very risky as happened in Heboh Sastra (literary commotion)in 1968 when Kipandjikusmin wrote about the prophet Muhammad related to the situation of Jakarta. However, religious themes always existed through the different eras and genres. In poems, God and religious experience constitutes hot issues and strong influence in the works of Indonesian young poets. Among the poets, Taufiq Ismail conveyed very strong religious belief in his poems, while Abdul Hadi was keen on his poems that were full of sound Islamic nuance. In prose, Ali Audah is a writer consistent with his Islamic belief and his translation of Arabic novels and short stories (Teeuw, 1994).

In the beginning of twenty first century, Islamic literature got its revival spirit through the fast growing publication of the so-called Islamic novels while until eight years before Indonesian literature was full of erotic novels known as satrawangi or 'fragrant literature' (Arnez, 2005, p. 1). Musa (2012) believes that the mushrooming of erotic literature by sastrawangi writers was the trigger of the revival of Islamic literature in this era beside the support of the entire society. Meanwhile, Hoesterey and Clark (2012) identify some factors, that is, the growing Islamisation process, the rise of Muslim middle class society, the increasing Muslims' involvement in politics, and the privatization of the media, supported by the freedom of expression in Indonesia in the post-New Order era. Rani (2012) labeled this kind of literary works as popular literature or popular Islamic novels.

In the various discussions of the recent phenomena of Islamic literature, that of specific focus on pesantren writers writing about pesantren has not been emerged. This can become space to enter. Among the literary works labeled as popular Islamic novels, specific phenomena can be identified, that is, the fact that works about pesantren by pesantren writers are very significant. The writers with pesantren background are among (if not the most of them) the best selling writers with the theme mostly about the life or the influence of pesantren. This phenomenon is obvious considering that the pesantren background writers spread in various groups based on the community, interest and age. At present there are considerably a large number of pesantren background writers writing about pesantren life supported by other aspects, such as the people's interest, the media, the publishing company, and the revival in religious aspect. As the really existing phenomena of contemporary Indonesian literature, the study on it is prominently important to do to give a broader picture of the entire facts about Indonesian literature at present time.

\section{Pesantren Tradition}

Pesantrens in Indonesia have so long history that to understand pesantren and its tradition needs the understanding of its history. Zamakhsyari Dhofier (1999) gives a comprehensive overview of it by giving the detail of pesantren history from early era when Islam first penetrated Java, in the era of Dutch control, to pesantren in contemporary era. His diagram of organizational structure of traditional Islamic education in Java gives a comprehensive description of pesantren. It starts from elementary Quranic chanting usually held by an ustadz(teacher) at home or little mosque followed by students from near surrounding, and then pengajian kitab (learning standard Islamic books) given by a pesantren leader in a mosque followed by more audience, next minor pesantren, secondary pesantren, and major pesantren with large number of students, well-organized and led by a well-known Kiai (religious leader).

The position of Kiaiis very important both for the santri (students of pesantren) and in the society. Kiai is not only the leader of pesantren but also a very important public figure among the society. Srimulyani (2008) describes that leadership in pesantren has various meaning. Kiai as the leader of pesantren has both internal duties, which deal with the management and academic matters of the pesantren, and external duties, which deal with his responsibility to the society. Within the pesantren, his general duties are to teach the kitabkuning (yellow books), that is, the source books or standard works of fiqh (Islamic jurisprudence), usulfiqh (systems of 
Islamic jurisprudence), hadith (traditions purporting to preserve the decision, actions, utterances of the Prophet Muhammad), adab (Arabic literature), tafsir (Qur'an exegesis), tauhid (Islamic theology), tarikh (the history of Islam), tassawuf (Sufism, and akhlaq (Islamic ethics) (Dhofier 1999, p. 4); to lead (be the imam) the students' communal prayers; to give religious speeches or advices to the students; and to conduct religious ceremonies and rituals. His external duties are to be religious leader for the society; to give religious preacher; to arrange general religious forum; and to be the source person for any problems of the people coming to ask solutions. This position places the Kiai as charismatic leaders and respected figures of the society.There is a mutual relationship between society and pesantren. Society needs spiritual support from pesantren and pesantren needs economic support from the society. The relationship also influences the position of the Kiai in the society (Jones, 1991, p. 21).

In pesantren, through everyday and on going teaching learning process, the students are encouraged learn continuously "from the cradle to the grave" (Dhofier, 1999: 6). For the students, it gives very strong spirit to study (Nilan, 2009). In spite the same spirit, there are some types of pesantren. Tan (2011) divides types of pesantren into traditional, which focus on traditional Islam and are affiliated with Nahdlatul Ulama (the biggest Indonesian Muslim organization); modern, introducing a structured grade system, classrooms, textbooks, and an ethos of reform and progress, and are affiliated with Muhammadiyah (the second Indonesian Muslim organization); and independent, which is not associated with both organizations. Dhofier (1999) categorized pesantrens into Pesantren salafi that teach classical texts and Pesantren khalafi that introduce secular subjects.

Among other educational institutions developing in Indonesia, the enrollment to pesantrens steadily increases (Azra et.al., 2007). Azra et.al. also present data that pesantrens have included many other academic instruction, not only religious, but also nonreligious and vocational instruction to fit the need of people in new era. The root of the kind phenomena could actually be traced from the earlier time. It had become a tradition in pesantren to give the students other skills than only studying classical texts in the earlier history of pesantren (Jackson and Parker, 2008). Therefore, it is not a new phenomenon, but nowadays the other skills provided to the students are more various and professionally managed (Rahardjo, 1986; Rais, 1987). In addition, pesantrens also have created a system he calls as a hybrid system of education that combines religious instruction and scientific and technical training LukensBull (2001). To Pohl (2007), the reason is that pesantrens have to respond to the development of education otherwise they will be left behind.

\section{Pesantren Literature}

As a new term in Indonesian literature, sastrapesantren (pesantren literature) invites debates regarding the appropriateness of the term to use in Indonesian literature when the first time it appeared in 1990s. There were at least two different opinions: the first is that pesantren literature really exists in Indonesian literature considering the existence of many writers from pesantren and the long literary tradition in pesantren; and the second is that the works by writers from pesantren are not different from other Indonesian writers in terms of literary features so their works are not appropriate to be categorized into different genre. The bridge between the two opinions can be found in the opinion of Ahmad Tohari (1997), one of the outstanding Indonesian novelists having pesantren background who said that the emergence of pesantren writers gave a new color to Indonesian literature that simultaneously blurred the border between pesantren and non-pesantren literature. For him, it is not objective to consider that pesantren literature exclusively belongs to santri; in fact it is an inseparable part of Indonesian literature.

The important point can start from the history of the emergence of the term. In Indonesian literature, there has not been the term sastra pesantren before the last years of twentieth century and the beginning of twenty first century with the emergence of many pesantren writers in 1990s and the booming of many novels written by writer with pesantren tradition. The label of sastra 
pesantren is used for the works by writers from pesantren. This gives a point that actually the term sastra pesantren is actually new in the history of Indonesian literature regardless the existence of literature in pesantrens since some centuries before.

The literary tradition in pesantrens can be traced from the very beginning in the era of the nine Saints who used literary works to proselytize and arrange new social order and history with the efforts to combine the existing literary tradition and the Islamic mission they bore with. This embryo then existed and developed accompanying the history of Indonesian literature as a whole. The first era until the nineteenth century before the era of Indonesian modern literature was characterized by Baso (2012) as that (1) being a writer was not the profession of this era pesantren writers since they have other profession like other common people as the strategy to approach the people; (2) pesantren literature in the form of hikayat, serat, kisah, story, poems, novelette, novel, syi'ir, and nadhoman became communal works due to the generation to generation transfer process, (3) pesantren became the basecamp for the pesantren writers to create their works; and (4) pesantren literature made the edit version, rewriting, addition and insertion, to suit with the pesantren social-religious ideas. According D. Zawawi Imron (2004), pesantren literature has existed since the coming of Islam in Indonesia in the twelfth century and could not be separated from Indonesian literature. In the first period of the coming of Islam, there were many literary works describing the life of pesantren, including the teachings, attitudes, tradition, culture, and even the upheaval happening inside the pesantrens. This condition and this kind of literary genre with its own characteristics have always grown until the beginning of the nineteenth century. The next phase was the phase of declination until around the last of the first half of the twentieth century. This phase is called as the revival of pesantren literature (Wahid, 1973). The paradigm in this phase changed because of the influence of modernism and colonialism. This phase can be divided into two main groups, the first, literary works that only include pesantren as the setting, and the second, literary works that can explore the soul of pesantren. The next phase is 1960s generation; for example, Djamil Suherman presented pesantren life in the early era with a strong religious influence presenting a story of young students of Islamic boarding schools based on his own experience in a pesantren in East Java in his short stories collection book Umi Kalsum (Sumardjo, 1992). He represented traditional Islam with the background of Pesantren (Teeuw, 1989). The next generations are in the 1970s Emha Ainun Nadjib; in the 1980s K. H. Mustofa Bisri, Jamal D. Rahman, Acep Zamzam Noor, and Ahmad Syubbahuddin Alwy; and in the 1990s Mathori A. Elwa, Hamdi Salad, Nasruddin Anshory, Kuswaidi Syafi'i, and Abidah El Khalieqy (NU Online, 2004).

Pesantren literature generally refers to literature concerned with the knowledge and traditions related to the pesantren system whose themes are about "religious expression and feelings of love for God, esoteric religious experience, concerns about human ethics, and praise for God's universe" (Ismah, 2011).In more specific definition, it refers to at least three kinds of literary works, that is, (1) literature that exists in pesantren, such as syi'ir and nadhoman; (2) literature written by writers from pesantren, they are kiais (the leaders of pesantren), santri (the students of pesantren), and alumni of pesantren; (3) literature containing pesantren as the theme, this refers to the works like UmiKalsum by Djamil Suherman and GeniJora by Abidah EKhalieqy. Based on the three definitions, pesantren literature is likely to develop to the broader scope outside the original form and content (Rahman, 2008). While Sony Farid Maulana emphasized sastra pesantren more to its relation to the background of the writers as ones who are or have been involved in pesantren tradition (Maulana, 2010). Munawar (2008) gives more general definition, that is, pesantren literature applies to literary works written by writers from Pesantren or Islamic boarding schools. From the definition, both Islamic literature and pesantren literature are alike in respect to their concern on the religious values, however the difference on the aspect of pesantren becomes significant through deeper analysis on it.

Those definitions are very open to all possible kinds of literary works produced in the area of pesantren tradition. They 
accommodate all possible debates on the existence of sastra pesantren.

Issues of pesantren writers as a specific group of writer have been discussed in several writings of some Indonesian literary critics. Their ideas give a basis of the arguments for this article concerning the existence of pesantren literature in Indonesian literature in spite of the limited specific studies on it. Well-known Indonesian literary critics A. Teeuw (1989) and Jacob Sumardjo (1992) recognize a prominent writer with pesantren background, Djamil Suherman, who wrote UmiKalsum (1963), a short stories collection about life and problems in pesantrens as Islamic traditional educational institutions that have great influences to the form of Indonesian Islam and Indonesian Muslims' way of thinking. A famous Indonesian novelist, Ahmad Tohari (1997), identified the existence of pesantren literature as an inseparable part of Indonesian literature and its contribution of giving new color to Indonesian literature. Moreover other prominent Indonesian pesantren writers, such as D. Zawawi Imron, Jamal D. Suherman, and Soni Farid Maulana also give great contribution to the clear definition of pesantren literature.

\section{Contemporary Indonesian Islam}

In the last decade Indonesia has experienced a very dramatic change since the fall of the new order regime in 1998. It was the change from authoritative government under Soeharto as the president, who was in power for about three decades, to democratic situation in all aspects of Indonesian life. Not only did the change happen in politic, social and economic aspects, but also in religious aspect. Concerning the religious aspect, Indonesian Islam was also influenced by the situation on the one hand, and influenced the possibility of the change to happen on the other hand.

In the era of Soeharto Islam, as Abdurrahman Wahid stated, was depoliticized and marginalized (Loveard, 1999), especially in the seventies and eighties, Islam experienced deconfessionalization, domestication, and marginalization (Effendi, 2005), and politically it has happened since 1960s (Hefner, 2000). Economically, in spite of the existence of rich Muslims, most of Muslims only had very small roles in the twentieth century Indonesian economy, which maintained the idea of capitalism (Mansurnoor, 2005). The government did not give opportunities and facilities for Muslims to improve and develop their capacities in order that they had the same chances as other groups of society who had been more modernized. In social aspect, the new order government restricted the influence of Islam in Indonesian civil life (Hefner, 1997).

In the unbeneficial condition, Islam were directed into cultural movement, the experts called this as 'cultural Islam' (Azra, 2000; Fealy, Hooker, \& White, 2006). Not involving in political affairs, Muslims developed the social and cultural basis. As a result, in the next decade, there was "the renaissance of Islamic religion and culture in Indonesia" (Azra, 2000). Starting from the late 1980s, the religious consciousness and interest in Islam among Muslims, specifically the young, revived and, in turn, it was followed by their stronger demands to voice their political aspiration (Schwarz, 1994). In 1990s, the Islamic cultural movements resulted in the rise of, among others, the number of mosques, madrasahs, hajji pilgrimages, Islamic Banks, and Islamic insurances. This, in turn, gave political implications. However, this era, in which the influence of Muslim social styles grew specifically among urban middle class Indonesians, increased Muslims' dignity to confess their faith, their pride to be Muslims, their devotion to God, and their observance of the Islamic teachings. Those were previously considered embarrassing, unfashionable, and probably unsafe for their careers (Hefner, 1997; Barton, 2001; Ramage, 1995). Cultural Islam has had considerable implications that gave great inspiration and spirit among Muslim intellectuals, scholars, and students. Accompanying cultural Islam, some movements also rose from campus, known as 'campus Islam', referring to some universitybased movements, namely Gerakan Tarbiyah (Education Movements), Hizbut Tahrir (Liberation Party) and Jamaah Tabligh (Preaching Community) (Fealy, Hooker, \& White, 2006). However, "Indonesia's santri community is in uneasy state. Conservative preachers remain preoccupied with the 'Christian threat' and disoriented by rapid 
economic growth and changes in society." (Schwarz, 1994, p. 189).

After Soeharto resigned and Habibie replaced his position as President, Muslims got more political access. The most apparent fact was the sharp increase of Islamic political parties declared after the three party system was formally abandoned and the 1985 Mass Organization Law that oblige all organizations to adopt Pancasila as the only ideology was abolished. According to Kuntowijoyo, it was only the Muslim political elites' expression of political euphoria after the marginalization and suppression in the era of Soeharto (Azra, 2000). Amien Rais (1999) identified it as "the beginning of the new chapter in Indonesia's history where Muslim are allowed to form parties representing their goals and interests, having been barred from doing so during the previous regime." In this era, with the growing strength of Muslim human resources, Islam has become a big power (Jamhari, 1999).

Soeharto's resignation resulted in the consciousness among Indonesian people to reform all the previous unsatisfying aspects of nation life. Muslims, supported by the growing change in the previous era, demonstrated more their consciousness to show their religious identities in public sphere. Islam then had important roles in political, economic, social, and cultural practices and could carry out their needs to implement the Islamic principles (Hasan, 2009). Culturally, the last decade witnessed the emergence of new Muslim in company with the new middleclass, urban-based and well-educated Muslims in the early decade from the mid 1980s to the mid 1990s that resulted in the dramatic change in Muslim identity. Islam is now close to the media and other modern symbols of modern society, such as television talk shows and business cards with $\mathrm{PhDs}$ from prominent Western schools. Since then, Muslims gained important economic and political positions that require them to enjoy the privileges and show their identities (Heriyanto, 2008).
The Islamic revival in Indonesia cannot be separated from the global Islamic revival of the last decades that created new figures of public piety and Islamic teachings spread as public interest. In the case of Indonesia, it is due to the wider growing middle class, the decrease of the restrictions to the media after Soeharto's era, and the expanding privatization of media that contributes to the emergence of symbolic and economic capital of Islam. In turn, Islamic brands and products are largely consumed, including Islam-themed novels (Hoesterey, 2012). In terms of Islamic literature publication, this was the era when Islamic books got specific attention from public. Such books could be found easily in the bookstore, supported by the omission of press censorship and bans to give a place for democratic freedom (Watson, 2005).

\section{CONCLUSION}

Understanding the position of pesantren literature cannot be separated from the understanding of the development of Islamic literature in Indonesia and Indonesian literature as a whole and the history of pesantren and Islam in Indonesia as well. The existence of pesantren literature in recent years results from a long history of Islam in Indonesia. The discussion above gives us perspective on how we place pesantren literature in the constellation of Islamic and Indonesian literature in a broader perspective. Pesantren literature emerged from pesantren tradition that developed from a long history of the development of Islam in Indonesia. Literature as a part of human life develops in line with what people concern with. Indonesian Muslims concern with Islam as their way of life. It also induces in their creative works, including their works of literature. Literary works concerning Islamic ideas are included in Islamic literature. Among the works, pesantren literature place themselves as a specific genre. 


\section{REFERENCE}

Abdullah, M. (1996). Puji-pujian : tradisi lisan dalam sastra pesantren. Warta ATL. Jakarta : Jurnal ATL.

Arimbi, DA. (2009). Reading contemporary Indonesian Muslim women writers: representation, identity and religion of Muslim women in Indonesian fiction. Amsterdam: Amsterdam University Press.

Arnez, M. (2009). Dakwah by the pen: reading Helvy Tiana Rosa's Bukaviï . Indonesia and the Malay World, 37 (No. 107),45-67.

Azra, A. (2000). The islamic factor in post-Soeharto Indonesia. In C. Manning \& P. V. Diermen (Eds.), Indonesia in transition: Social aspects of reformasi and crisis (pp. 309-318). Singapore: Institute of Southeast Asian Studies.

Azra, A, Afrianty, D \&Hafner, RW. (2007).Pesantren and madrasa: Muslim schools and national ideals in Indonesia. In Hefner RW \& Zaman MQ (eds.),Schooling Islam: the culture and politics of modern Muslim education(pp. 172-198). New Jersey: Princeton University Press.

Barton, G. (2001). The prospects for Islam. In G. Lloyd \& S. Smith (Eds.), Indonesia today: Challenges of history (pp. 244-255). Singapore: Institute of Southeast Asian Studies.

Baso, A. (2012).Pesantren studies 2b/buku II kosmopolitanisme peradaban kaum santri di masa kolonial juz II sastra pesantren dan jejaring teks-teks aswaja-keindonesiaan dari wali songo ke abad 19. Jakarta: Pustaka Afid.

Candraningrum, D. (2007). The quest for Islamic identity: Helvy Tiana Rosa's call for universal brotherhood (Ummah) and the return to total Islam (Kaffah). Orientier- ungen, 2, 101-27.

Dewi, N. (2011). Formation of youth in Indonesian Islamic chick lit. Kata, 13 (No. 1), 134-146.

Dhofier, Z. (1999). The pesantren tradition: the role of the kyai in the maintenance of traditional Islam in Java, the Program for Southeast Asian Studies. Tempe, Arizona: ASU.

Effendy, B. (2005). What is political Islam? An examination of its theoretical mapping in modern Indonesia. In C. S. Bamualim (Ed.), A portrait of contemporary Indonesian Islam (pp. 1-26). Jakarta: Pusat Bahasa dan Budaya UIN Syarif Hidayatullah Jakarta and Konrad-AdenauerStiftung (KAS).

Fealy, G. (2008). Consuming Islam: commodified religion and aspirational pietism in contemporary Indonesia. In Fealy $\mathrm{G}$ and White $\mathrm{S}$ (eds.), Expressing Islam: religious life and politics in Indonesia (pp. 15-39). Singapore: Institute of Southeast Asian Studies.

Fealy, G., Hooker, V., \& White, S. (2006). Indonesia. In G. Fealy \& V. Hooker (Eds.), Voices of Islam in Southeast Asia: A contemporary sourcebook (pp. 39-50). Singapore: Institute of Southeast Asian Studies.

Hefner, RW. (1997). Islamization and democratization in Indonesia. In R. W. Hefner \& P. Horvatich (Eds.), Islam in an era of nation-states: Politics and religious renewal in Muslim Southeast Asia (pp. 75-127). USA: University of Hawai'i Press.

Hellwig, T. (2011). Abidah El Khalieqy's novels: challenging patriarchal Islam. Bijdragen tot de Taal, Land- en Volkenkunde, vol. 167, no. 1, pp. 16-30. KITLV, Royal Netherlands Institute of 
Southeast Asian and Caribbean Studies, viewed 5 April 2013, $<$ http://www.jstor.org/stable/41203119>.

Heriyanto, A. (2008). Pop culture and competing identities. In Heriyanto A (ed.), Popular culture in Indonesia: fluid identities in post-authoritarian politics (pp. 1-36). London and New York: Routledge.

Hoesterey, JB. (2012). Prophetic cosmopolitanism: Islam, pop psychology, and civil virtue in Indonesia. City \& Society, 24 (No. 1), 38-61.

Hoesterey, JB, Clark, M. (2012). Film Islami: gender, piety and pop culture in post-authoritarian Indonesia. Asian Studies Review, 36 (No. 2), 207-226.

Imanda, T. (2012). Independent versus mainstream Islamic cinema in Indonesia religion using the market or vice versa? InBaumgartel T (ed.), Southeast Asian Independent Cinema(pp. 91-104). Hong Kong: Hong Kong University Press.

Imron, DZ. (2004). Sastra pesantren. Kompas Cyber Media, viewed 10 October 2010, $<$ www.kompas.com>

Ismah, N. (2011). The new generation of women writers from the pesantren tradition in Indonesia. Explorations: a graduate student journal of Southeast Asian studies, 11 (No. 1), 105-12.

Jackson, E \& Parker, L. (2008). Enriched with knowledge: modernisation, Islamisation and the future of Islamic education in Indonesia [Paper in: Islamic Education in Indonesia.] [online]. Review of Indonesian and Malaysian Affairs, 42 (No. 1), 21-53. Viewed 10 March 2013, <http://search.informit.com.au.ezproxy.library.uq.edu.au/fullText;dn=200808962;res=APAF T> ISSN: 0815-7251.

Jamhari. (1999). Islamic political parties: threats or prospects? In Forrester G (ed.), PostSoeharto Indonesia: Renewal or chaos (pp. 181-186). Bathurst, NSW: Crawford House Publishing.

Jassin, HB. (1954/1985). Kesusasteraan Indonesia modern dalam kritik dan esai I. Jakarta: PT Gramedia.

Jones, S. (1991). The Javanese pesantren: between elite and peasantry. In Keyes CF (ed.), Reshaping local worlds: formal education and cultural change in rural Southeast Asia(pp. 19-41). New Heaven: Yale University Southeast Asia Studies.

Loveard, K. (1999). Suharto: Indonesia's last sultan. Singapore: Horizon Books.

Lukens-Bull, RA. (2001). Two sides of the same coins: modernity and tradition in Islamic education in Indonesia. Anthropology and Education Quarterly, ISSN 0161-7761, 32 (No. 3), 350-372, viewed 7 March 2013, <onlinelibrary.wiley.com.ezproxy.library.uq.edu.au>

Maulana, SF. (2010). Sastra, ulama, dan pesantren, viewed 28 August 2013, <http://komunitassastra.wordpress.com/2010/10/12/sastra-ulama-dan-pesantren>

Munawwar, R. (2007). Ledakan sastra pesantren mutakhir: cinta, kritisisme, dan industry. Suara Karya Online, viewed 5 May 2005, <www.suarakarya-online.com/news.html?id=167741>

Musa, MF. (2012). Fenomena sastra Islami di Indonesia. International Journal of the Malay World and Civilisation, I man (No. 30(1)),41-53. 
Nilan, P. (2009). The 'spirit of education' in Indonesian pesantren. British Journal of Sociology of Education, 30 (No. 2), 219-232.

NU Online, 'Zawawi Imron: sastra pesantrenbagian dari sastra Indonesia', viewed 15 August 2013, $<$ http://www.nu.or.id/page.php>

Osman, RAH \&Nasir MS. (2011). A Bird's eye view on the Islamic literature discourse in Indonesia. International Journal of Business and SocialScience, 2 (No. 11), 101-109.

Pohl, F. (2007). Islamic education and civil society: reflections on the pesantren in contemporary Indonesia. In Kadi W \& Billeh V, Islam and education: myth and truths (pp. 83-103). Chicago:The University of Chicago Press.

Rahardjo, MD. (1986). The life of santri youth: a view from the pesantren window at Pabelan. Journal of Social Issues in Southeast Asia, 1 (No.1), 32-56, viewed 8 March 2013, $<$ http://www.jstor.org/stable/41056694>.

Rahman, JD. (2008). Sastra, pesantren, dan radikalisme Islam, viewed 10 June 2010, $<$ http://jamaldrahman.wordpress.com/2008/10/25/sastra-pesantren-dan-radikalismeislam/>

Rais, MA. (1987). Muslim in society, higher education and development: the case of Indonesia (1). In Ahmat S \& Siddique S, Muslim society, higher education and development in Southeast Asia (pp. 9-27). Singapore:Institute of Southeast Asian Studies,.

Ramage, Douglas E. (1995). Politics in Indonesia: Democracy, Islam and the ideology of tolerance. London: Routledge.

Rani, MZA. (2012). Islam, romance and popular taste inIndonesia. Indonesia and the Malay World, 40 (No. 116), 59-73, viewed 6 April 2013, <http://dx.doi.org/10.1080/13639811.2011.648998>

Rosa, HT. (2003). Segenggan guman: esai-esai tentang sastra dan kepenulisan. Bandung: Syaamil Cipta Media.

Said, WE. (2004). Humanism and Democratic Criticism. New York: Columbia University Press.

Sen, K (2011). Introduction: re-forming media in Indonesia's transition to democracy. In Sen K \& Hill DT (eds.), Politics and the media in twenty-first century Indonesia: decade of democracy. New York: Routledge.

Sirry, M. (2010). The public expression of traditional Islam: the pesantren and civil society in postSuharto. The Muslim World,100 (No. 1), ProQuest Research Library, 60-77.

Srimulyani, E. (2008). Pesantren Seblak of Jombang, East Java: women's educational leadership [Paper in: Islamic Education in Indonesia.], Review of Indonesian and Malaysian Affairs, 42 (No.1), 81-106, viewed 10 March 2013, <http://search.informit.com.au.ezproxy.library.uq.edu.au/fullText;dn=200808964;res=APAF T> ISSN: 0815-7251.

Srimulyani, E. (2007). Muslim women and education in Indonesia: the pondok pesantrenexperience. Asia Pacific Journal of Education, 27 (No. 1), 85-99.

Sumardjo, J. (1992). Lintasan sastra Indonesia modern 1. Bandung: Citra Aditya Bakti. 
Schwarz, Adam. (1994). A nation in waiting: Indonesia in the 1990s. St Leonards, NSW: Allen \& Unwin.

Tan, C. (2011). Islamic education and indoctrination: the case in Indonesia. New York: Routledge.

Teeuw, A. (1989). Sastra Indonesia modern II. Jakarta: Dunia Pustaka Jaya.

Tohari, A. (1997). Sastra pesantren, sastra dakwah. Jawa Pos (Minggu, 28 September 1997)

Wahid, A (1973). 'Pesantren dalam Kesusasteraan Indonesia', Kompas (26 November 1973).

Watson, CW (2005). 'Islamic books and their publishers: notes on the contemporary Indonesian scene', Journal of Islamic Studies, vol. 16, no. 2, pp. 177-210. 